Portland State University

PDXScholar

$5-31-1977$

\title{
An Assessment of the Impact of Public Housing on the Low Income Elderly Residents of the Burnside Community
}

Timothy C. Jacobs

Portland State University

Follow this and additional works at: https://pdxscholar.library.pdx.edu/open_access_etds

Part of the Social Work Commons

Let us know how access to this document benefits you.

Recommended Citation

Jacobs, Timothy C., "An Assessment of the Impact of Public Housing on the Low Income Elderly Residents of the Burnside Community" (1977). Dissertations and Theses. Paper 1882.

https://doi.org/10.15760/etd.1881

This Thesis is brought to you for free and open access. It has been accepted for inclusion in Dissertations and Theses by an authorized administrator of PDXScholar. Please contact us if we can make this document more accessible: pdxscholar@pdx.edu. 


\title{
AN ASSESSMENT OF THE IMPACT OF PLBLIC HOUSING ON THE LOU INCOME ELDERLY RESIDENTS OF THE BURNSIDE COMMUNITY
}

\section{by}

\author{
TIMOTHY C. JACOBS
}

A practicum submitted in partial fulfillment of the requirements for the degree of

\author{
MASTER OF SOCIAL WORK
}


TO THE OFFICE OF GRADUATE STUDIES AND RESEARCH:

Professor Gerald Frey, Ph.D. approves the practicum of

Timothy C. Jacobs presented May 31, 1977.

Gerald Frey, Ph.D. 
TABLE OF CONTENTS

PAGE

LIST OF TABLES ........................ IV

CHAPTER

I INTRODUCTION . . . . . . . . . . . 1

II THE BURNSIDE COMMUNITY ............. 3

A Historical Sketch .......... 5

Who Lives on Skid Row? . . . . . . . 11

III HOUSING TRENDS FOR SKID ROW COMMUNITIES

IN OTHER CITIES ............... 21

IV HOUSTNG TRENDS FOR GLURSIDE .......... 26

The Decline of Low Income Housing . . . . . 26

Social Policy: Implications for Housing • • 29

Developing New Housing ......... 33

V THE FOSTER HDTEL ................... 35

The Study

Purpose ................... 40

Study Design and Methodology ....... 40

Results ................ 41

Identifying Information . . . . . . . 42

Determinations Made .......... 43

Implications ............. 53

VI CONCLUSION ..................... 56

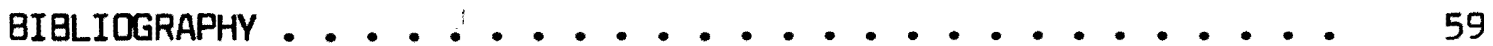




\section{LIST OF TABLES}

TABLE

PAGE

I Gender of Foster Hotel Residents . . . . . . . . 42

II Ever Lived In Foster or Friendly Home Hotel . . . . .. 44

III Lived in Foster or Friendly Home Hotel Immediately

Prior to Closure . . . . . . . . . . 44

IV Area Lived in Prior to the Foster . . . . . . . 46

V Number of Years Lived on Burnside . . . . . . . . 46

VI Types who should be at Foster . . . . . . . . 47

VII Types who Should be Kept Dut of Foster . . . . . . . 48

VIII Attitudes about Chronic Alcoholic .......... 48

IX Attitudes about Severely Disabled .......... 49

X Advantages of Foster .............. 50

XI Disadvantages of Foster ............ 50

XII Crimes Occurring in Foster . . . . . . . . . . 51

XIII Status of Security at Foster . . . . . . . . . 51

XIV Should All Burnside Housing be Public? . . . . . . . 52

XV Does Private Housing Have Place on Burnaide? . . . . . 52 


\section{CHAPTER I}

\section{INTRODUCTION}

Looking back over the six years I have spent in the Burnside area I can only say that I love it. My roots are here and I am here. Like all of you I wish to live out my declining years here in the Burnside area. But will there be a Burnside like we know it? Will the tramp be accepted in this area which he helped to build? We are quickly losing our vital housing stock. Chapter 13 and business renewal is eating away at our homes and flophousegs that gave us shelter and housed us cheaply and adequately.

The sentiment expressed by Everett Lyons in this speech accurately describes the situation in the Burnside area. People who have built the neighborhood, lived in it and called it home for years are gradually being forced to move as their housing is being destroyed or converted into commercial enterprises that cater to the middle class. As a result the older Burnside area resident is forced to move out of an area that he has lived in for years.

This study will be a look at housing for Portland's Burnside population with special emphasis on the foster hotel public housing project. Before housing or any other aspect of Burnside can be intelligently discussed, it is important to have a realistic historical and contemporary understanding of the Burnside community. The secortd chapter of this study is designed to provide that understanding. The third chapter surveys the ways that other American cities have dealt with their skid row com-

${ }^{1}$ Excerpt from a speech by Everett Lyons, president of the Burnside Area Aresidents, delivered to the Burnside Voter's Forum on May 10, 1976, at the Downtown Chapel, Portland, Oregon. 
munities. Cities roughly the same size as Portland were chosen. Their efforts will be compared to Portland's plans for and actions toward its Burnside area - the subject of Chapter IV.. In this chapter a critical analysis of the social policy recommendations made by the Human Resources Bureau for the downtown urban renewal area is offered as this is the official public social policy for the area. The next chapter of this study presents a survey done of the foster hotel to determine whether or not it is meeting the needs of the community. When the foster was initially planned, certain promises were made about who would be housed there and how it would serve Burnside. The questionnaire given to the Foster residents was designed to see if those promises were kept and to guage the overall satisfaction the residents have with the hotel. It is hoped that with the background material provided in the first chapter of this study, a context will be established within which the reader can understand housing as it relates to this community. 


\section{CHAPTER II}

THE BURNSIDE COMMUNITY

My rent is high, my cash is low,

And I'm caught in between.

My landlord drives the longest, fastest

Car you ever seen.

My walls are thin, my carpets too,

My ceilings are like sieves;

But you should see the lovely mansion

where my landlord IIves.

They tell me it's monopolies

Oun everything I see,

So I'll be on the market sonn

'Cause they own most of me.

And after they have processed me

And wrapped me up so nice,

They'll send me right back to myself

At some gawd-awful price.

The general understending of the character and make-up of skid row communities has always been shrouded in misconceptions. Even the designation that the community has received has caused some controversy. The designation for Burnside and other similar areas of large cities has been

both "skid row" and "skidroad." The arguments for each are given below.

Skidroad is the proper name. It originated in Seattle some [ninety-five] years ago, when logs were hauled through the town over an actual skidroad made of logs laid crosswise. Hotels, saloons and other places seeking the logger trade grew up along the skidroad and the entire district was known as the skidroad. From Seattle the term spread until cities all over the west had their skidroad districts. of recent years a corruption has appeared as "Skidrow" but its use is confined to those who wish to be known as men of French.

This verse is taken from the song "Out of Your Pocket" by Bryant 
the world, and who patently don't know what they are talking about. (Holbrook, 1952: 247)

Here Holbrook's history is accurate, however, he doesn't account for how eastern cities came to use the term skid row. Another account of these terms goes like this,

The term 'Skid Road' has been used in place of Skid Row by sociologists, anthropologists, geographers, city planners, politicians and the media who are unfamiliar with such urban areas. A Skid Road is a dirt road used by loggers to transport logs to the river, mill, or 'cold deck,' by skidding them over unlaid logs . . Skid Row, on the other hand, is an urban term that came into existance after the Civil war when homeless and famililess individuals, drug addicts, alcoholics, criminals, and ex-cons began congregating in a visible blighted area. As its population and size increased after each war, such areas became known by its inhabitants as "Death Row" - a place a man goes to die. (Jones, 1973: 2)

Which one is correct? In this author's experience in working on Burnside, the term used by the residents is skid row and not skidroad. Since this is a paper about their community, this author will favor the term used by the residents - skid row.

The people living on skid row are generally thought of as "drunks," "bums," or "shiftless" men who have somehow fallen to the lowest form of living in our society. Before any description of housing and housing needs for this community can be made, an accurate understanding of the historical nature of the community as well as a precise reading of the demographic characteristics of the people who live there'is necessary. This chapter will begin to show evidence that Burnside and other skid row communities historically have been workingmen's communities. In the past they have served to provide a source of cheap labor for big industry and to a smaller extent continue to do so today. The concept of skid row 
as a workingman's community will provide a cultural framework within which the reader may better understand the community. This chapter will then go on to describe some of the specific conditions commonly associated with skid row areas, e.g. alcoholism, crime, the transient status of its residents, etc. The study will then show how these conditions relate to Burnside as a warkingman's community. With this understanding of the community and the problems associated with it, we can begin to see how the housing needs fit into this community picture.

\section{A HISTORICAL SKETCH ${ }^{2}$}

Ever since Portland started out as a small toun in the mid-1800's, the Burnside community has been the home of countless loggers, railroad workers, seamen, longshoremen, farm workers, factory workers, and various skilled and unskilled laborers. As Portland and other large cities began to grow and prosper, largely as a result of increased exploitation of natural resources, they needed a large pool of laborers to do the work their industrial needs demanded. Often they looked to the Burnside community as a source of cheap labor to be used to meet those demands. The neighborhood itself has always been populated primarily by single men and historically its social and economic institutions have been designed to meet the needs of this population.

${ }^{2}$ This part of the paper was difficult to prepare because there is no accurate, thorough, well-documented account of the history of Burnside. Though its past is quite colorful, little work appears to have been done by local historians to collect and explain it. Historians usually point their efforts toward describing the major political and cultural events of the wealthy and the people who control the commercial activity. Since Burnside is a community of the "common" workingman, the recording of its existence has been ignored by most local historians. 
In the Pacific Northwest and perticularly Portland, logging and the proceseing of wond beceme the Plrst major economic endeavor. Early Portland Industrialists saw the immense profit to be made in lumber and wers quick to begin exploiting the erea's resources. Portland, itself, becane the leader in the lumber industry in 1850 when the first steam powered sawnill was built on the west benk of the Willamette. (Holbrook, 1956: 167). This saumill and other events allowed Portland, which was then no larger than Astoria, Oregon City, and Vancouver, to become the major industrial center far this region.

Getting the logs out of the forest and to the saumill, became a problem in the Pacific Northwest woods. The ground wes either too soft or too rough to drag the logs over it as had been done in the East. In order to overcome this problem, a system unique to this area was developed - the skidroad. In his account of logging in the United States, Stewart Holbrook offers the following description of the skidraad.

The skidroad was the western loggers' first and greatest contribution to the science of noving timber. They first cleared a path in the forest. At suitable intervals they filled trees across this path, cut them free of limbs, then buried them half-deep in the soft ground. These were the skids that made a skidroad, a sort of track that would keep logs from hanging up on rocks or miring in mud. The completed job looked not unlike ties laid for a gargantuan railroad. (Holbrook, 1956: 163-164)

One end of the skidroad would be deep in the timber where the felling of trees was occuring. At the other end would be the saumill where the trees would be turned into lumber. The logs would then be cut, put on the skidroad and pulled to the sawill for processing. If the sawmill was not handy, the logs were pulled to rivers where the trees could be bound together and floated down to the samills. As more logs were 
being brought into Portland for processing, more skidroads were b. transport those logs. Many of these skidroads eventually became Portland streets. (Holbrook, 1956: 167). Thus the town of Portland grew up around its logging industry.

As Portland depended on the logging industry for its econamic survival, so too did logging depend a a cheap source of labor for its operation. People were needed to cut the trees, to trim them, to transport thern to the saumill, and to operate the sawmills. As these working people cane to the Northwest to etch out a living, they needed a place to live and to recreate. To meet this need, an area of Portland developed that housed the various life support institutions that catered to the workingclass male. This area became known as Burnside or the old North End. ${ }^{3}$ In discussing Burnside and other skid row communities Stewart Holbrook has described their earlier flavor as . . that part of town where loggers and other footloose
men were wont to relay periodically, usually in July and
December. It presented, until quite recently, block upon
block of rooming houses, houses of gasy virtue, beer joints,
pool halls, tatoo parlors, burlesque theaters, an Iuld or
wobbly hali, and the kind of store that has a pile of paper
suitcases on openhanded display near the entrance, with
every one chained down. (Holbrook, 1952: 247)

Lhen their work brought them into Portland, workingmen often congregated in Burnside drinking establishments - most notably Erickson's.

${ }^{3}$ The North End was a name frerjuently used when referring to the area north of Burnside Street. The fact that a name developed to rof to this area of town indicates that Burnside has always had an individual character and identity that sets it apart fron the rest of Portland. The name "old Town" frequently used by commercial developers, urban planners, and others who want to exploit the area's history without really understanding it, has no historical basis. 
Designated as the Workingman's Club, Erickson's served as a meeting place for loggers who were temporarily or permanently living in Portland. Founded In the 1880's, Erickson's still stands today on the corner of $3 \mathrm{rd}$ and Burnside and still carries the designation of "The Workingmen's Club." It became a landmark in Portland and the Northwest. It was known for its conversant bartenders, its good whiskey, its grand paintings, a $\$ 5000$ pipe organ, its free lunch, and 1ts bar. At exactly 684 lineal feet Erickson's claimed, with no little pride, of having "the longest bar in the world." workingmen from all over the Northwest came to Erickson's and "discussed almost, but not quite, everything over their beverages. Jobs, wages, working conditions were popular subjects. Stupendous feats of work were bragged about; so too noble stints of love-making." (Holbrook, 1952: 82). Though much smaller today than it was in earlier years, Erickson's still stands continuing to serve the workingmen of Portland who congregate in the Burnside area.

Other institutions flaurished in the Burnside area that served primarily or exclusively male clientele and catered primarily to workingclass people. Employment agencies (also known as "slave markets" and considering the wages at that time this designation seems quite appropriate), tatoo parlors, bath houses, gambling halls, and houses of próstitution were common to the area. Of the latter the most famous was the Paris House. It was housed on the 2nd and 3rd floors of a block-long building on Davis Street between Third and Fourth Avenue and is said to have emplayed over 100 women. It stood until 1907 when it was closed in a fit of 
"morality" by local reformers." (Holbrook, 1956: 201)

Perhaps the best example revealing Burnside as a working class community was the practice of procurfing unwilling men for work aboard oceangoing vessels. This practice, known as "crimping" or "shanghailng" was cammon on Burnside until the 1920's. Workingmen, frequenting Burnside area bars and rooming houses, would be drugged and taken unconscious through tunnels underneath Burnside streets, out to the waterfront where they would be turned over to a ship's captain. (Pintarich, 1976)

The ship would then set out to sea and be faraway from shore by the time the men woke up. Once at sea they could not leave ship and thus they became sailors for the remainder of that voyage. The people doing the procurfing, called "crimps," got from $\$ 25$ to $\$ 50$ for each man they delivered. (Holbrook, 1956: 201-202). The fact that the crimps went to Burnside in order to get the labor force they needed provides another example of how the Burnside area has served Portland industry by supplying it with a low cost labor force.

Other evidence showing Burnside as historically being a workingman's quarter can be seen by the presence of the Industrial workers of the World. The I.W.W. or "wabblies" began organizing Northwest loggers and saumill workers around the turn of the century. In March, 1907, having gained some power and momentum, the I.W.W. began to call for strikes.

They struck first in Portland, where all except one of an even dozen large sawmills were forced to close. It was scandalous, an unheard-of thing in the lumber industry of the Pacific Northwest; and retaliation was prompt. Police arrested scores of wobs and clapped them into jail on charges ranging from dis-

${ }^{4}$ It is perhaps more than coincidental that this is also the year that 11 of Portland's 12 sawills were struck by the I.W.W. The closing of the Paris House may have been more a retaliatory gesture on the part of Portland's wealthier oitizens than a "fit of morality." 
orderly conduct to attempted arson. The strike was soon broken but lumbermen were jittery at this first attempt to organize their notoriously unorganized employees. (Holbrook, 1956: 211)

The wobblies then went on to organize in Seattle, Spokane and other Northwest cities with the locus of this organization always occuring in the skid row section of town. By 1908, the Northwest wobs were so well-organized they sent a delegation to the I.W.W. convention held in Chicago that year. This delegation, known as the "overall brigade" dominated the convention and encouraged other loggers to begin striking. Following the convention, strikes broke out in logging centers all across the United States. Though largely unsuccessful, the effort did show that loggers and other workingmen living in Northwest skid row areas were becoming conscious of the economic realities of their existence. (Holbrook, 1956: 213)

Burnside, or the Old North End, has always been a workingman's community supplying Portland's industrialists with a constant source of cheap labor. As lumber, shipping, farming, railroads, and ractories began operating in Portland, the need for inexpensive labor increased and the Burnside community expanded. Various institutions catering to the workingclass male began operating on Burnside making it truly a home to this individual. He could thus reside in its rooming houses, work out of its "slave markets" or employment agencies and entertain himself at its numerous bars, houses of prostitution and other institutions. As he got older, he could retire in its low rent hatels, living in the community he had come to know as home. Though the community had been set up primarily to exploit his strength as a younger man, it became the only community he knew. To not be able to 
retire in it means pulling up his roots and transferring them to an area unfamiliar and uncomfortable - an area not set up to cater to the needs and tastes he has acquired after years of a life in a community quite different than any other in the city.

Burnside served Portland well until the end of World War II. By then the unions for the lumber industry, the railroads, the shipping and dock workers and many factories were organized well enough that they could demand a living wage. The man working in these industries could afford to live in more expensive parts of town and often did. For this and other reasons, the population of the Burnside area began to decline. It still served as a source of cheap labor for agriculture and other industries whose labor force had not yet been organized to demand adequate monetary compensation for the work they performed.

With these changes of the last thirty years have come changes in the character of the Burngide community. From its beginnings it has always been a community that the workingman and the retired workingman have called home. But just who lives there and what kind of life they lead will be the subject of the next part of this chapter.

\section{WHO LIUES ON SKID ROW?}

The first part of this chapter presented historical evidence showing Burnside as a community of workingclass people. This part will take some of the common assumptions made about the character of this neighborhood (and all skid row neighborhoods), show their degree of validity (or invalidity), and explain their existence in the context of the workingman's community. What is sometines assumed to be examples of innate character weakness can often be better understood as reactions to exploitative 
economic and social systems that stand to gain from having a large pool of poorly paid working people.

Since entire books have been written on the subjects about to be covered, this should not be considered an exhaustive portrayal. What is intended rather, is threefold. First to show the extent to which various characteristics attributed to skid rows exist by the use of empirical data collected from the Burnside community and skid rows of ather cities. Secand, to show how these characteristics are expressions of a warkingclass reacting to some social and economic realities they are faced with. Third, to explain how any system of housing for this area needs to take into consideration, the very specific characteristics endemic to this community.

Perhaps the greatest single characteristic attributed to skid row communities is what many believe to be an inordinately high degree of alcoholism. Because drinking and inebriated men are highly visible here, skid rows have the image of being urban collecting points for men from all walks of life who by virtue of their inability to control their drinking, have hit the "skids" and wound up on skid row.

Though this is certainly a problem in this area, its origin and scope is much different than most people realize. Studies done in New York, Philadelphia, Chicago, and Minneapolis, show that only $1 / 3$ of the residents of their respective skid rows could be classified as heavy drinkers with even fewer (5-15\%) reaching the drinking habits of the chronic alcoholic. (Bahr and Caplow, 1974: 248). The majority of people living in these communities are only light, or moderate drinkers, with a significant minority displaying total abstinence.

The other assertion holding that many people living on skid row were 
former bankers, lawyers, etc. is largely myth. People who are knowledgable about skid row today tend to dispute this claim as untrue. Consider this appraisal by Ralph Friedman, a frequent visitor to the Burnside area:

Another fallacy nourished by the middle class, which seeks to absolve itself of awareness by contending that the downfall of men lies in their own defects, is that a high percentage of the Skid Road habitants are former professionals - doctors, lawyers, teachers, musicians and the like. You hear it said: "Some of the brainiest people in the country are bums on Skid Road. Its full of intellectuals - a lot of college graduates are there."

It is not so now and it was not so when I knew intimately the Skid Roads of America, including Portland. From time to time you came across a man who had once been someone of importance, generally in a minor way, or who had had a profession. But these men were rare. The formal intellectuals, that is, men with the proper academic background, were about as scant as rich men posing as beggars (another fallacy). (Friedman, 1967: 17)

The excessive drinker also lives a much different lifestyle than the chronic alcoholic. Drinking often takes on the function of giving the man a reason to socialize. The drinker is usually the member of an informal group - the bottle gang - who must share money to purchase the bottle or "jug," and eventually share the "jug" itself. This gives him a reason to talk and be talked to and fights the lonliness that can often accompany an unattached lifestyle. The alcoholic, on the other hand, wants nothing to do with others. He does not share his money to buy alcohol and will drink alone. His purpose in drinking is not to socialize but to satisfy his craving for alcohol. (Wallace, 1968: 102)

Drinking in skid row communities can also be better understood as a function of the lifestyle of the workingman. As mentioned earlier, Burnside has always been a community that has provided entertainment alternatives for the workingman. Alcohol consumption has historically always been one of those alternatives. In this predominately male community, great feats of drinking are often tied in a positive way to male identity, 
i.e. a raal man or a hard working man can drink with the best and hold his liquor. (Holbrook, 1952: 80). Thus drinking has always been a part of the lifestyle of the warking class male who has resided in this community. Indeed, as one is relegated to the position of doing the most strenuous work society has to offer, and receiving the lowest pay for it, it could be argued that skid row inhabitants are "driven to drink." when one is allowed few pleasures in life, alcohol may take on much greater importance. Whatever the "cause" of drinking on Burnside and other skid rows, the important aspect of it for purposes of our present discussion is the degree of its existence today. The chronic alcoholic and heavy drinker constitute about $1 / 3$ of most skid row communities. Though there is na good data on the degree of alcoholism in the Burnside community, it is probably safe to assume that the percentage here is the same. The importance of this as it relates to housing in this community is simply this: any plans for providing housing for residents of Burnside must make special provision for those residents who are alcoholic. His physical health, his ability to get along with other tenants, his capacity for self care, as well as his drinking habits need to be considered in any housing plan for this community. He cannot be cast aside as an "undesirable" who has no stake in the community - a community in which he has helped to build and called his home for years.

A set of characteristics that are probably more descriptive of the : tramps who live in Burnside is their age and disability status. Burnside. and other skid row areas are now the hame of many older and disabled people who are in need of low income housing. According to the 1970 U.S. Census 
figures ${ }^{5}$ for tract 51 , which includes the Burnside area, the average age was 53.9 years. When divided into categories that cover spans of ten years, the single largest category is for those between 55 to 64 years of age.

But there is another aspect to age and aging in this community that must be considered. Because occupations of skid row men are the most strenuous and under the worgt conditions that society has to offer, there exists a tendency for the residents to age faster and die sooner. In a survey of Chicago's skid row, Donald Bogue discovered that fully $2 / 3$ of the employed population were laborers and service workers. (Bogue, 1963: 180). In the same group he also found that ". . at most ages, 5kid Row inhabitants can expect to live less than $1 / 2$ the number of years remaining to men of the same age in the general population." (Bogue, 1963: 225). Caplow and Bahr in their research series looking at conditions in New York's Bowery and six other skid row areas concur. They state, "It is apparent in the occupational distributions that most skid row men are either service workers or laborers." (Bahr and Caplow, 1974: 38). Again, this evidence supports the assertion that skid row areas supply our society with a ready pool of workers to do the low paying jobs that no one else will do. As they perform this physically taxing work, they age quicker and die sooner. Chester Hartman, in his book documenting San Francisco's destruction of its skid row community, sums this point up nicely. He states,

In addition to fostering, sustaining, and relying on this

${ }^{5}$ with Burnside, as with any poverty area, there is a good chance that the area has been undercounted. Since most of the demagraphic information available for Burnside contained in this report comes from the 1970 census, it is important to keep this qualification in mind when reading this material. 
industial reserve army of job-hungry men, capitalist development as it occurred in California and other western states used up men in another sense. Exposure to the elements in rural jobs, the hazards of mining, logging, and construction work, lack of medical attention, insufficient diet and arduous work made men either unable or unwilling to continue. Men wore out early, with little provision by society for premature old age and premature retirement . . (Hartman, 1974: 95)

Tied in with the issue of premature aging and death is the health status of Burnside and other skid row residents. As one might suspect from the conclusions presented above, a man living in skid row is more likely to be chronically ill than men not living on skid row. Donald Bogue in his presentation of research he made in Chicago's skid row area reveals data that support this conclusion. He found that illness has more than twice the disabling effect on skid row residents than it had on the general male population. (Bogue, 1963: 203). He also found that there is a large group of skid row workingmen who are non-drinkers and who have suffered a major breakdown in health. (Bogue, Ibid: 211). These men come from workingclass backgrounds (laborers and service workers) and their illness has made them non-productive. Consequently, they live on skid row in a condition of poverty even more severe than for those who work and are paid substandard wages.

In summing up the research he did into the frequency of illness in skid row areas, Bogue states,

Residents of Skid Row are disabled from illness to a far greater extent than the general male population of the same ages. This excessive illness is not due to acute and infectious diseases so much as to chronic ailments . . A high percentage of the men suffer from severe and multiple chronic disorders, and, as consequence, they are partially disabled or handicapped for employment. (Bogue, Ibid: 215)

In the Burnside area, illness and disability account for a disproportionately high share of the population. The 1970 census shows that about $23 \%$ of the population under 65 are not in the labor force due 
primarily to disability. This does not include people over 65 who comprise $21 \%$ of the population and who also suffer from varying degrees of disabling conditions. The disease and illnesses consist of tuberculosis, heart diseases, respiratory and digestive problems, ulcers, conditions of the bones and joints, etc. These conditions are further exacerbated by exposure to the elements, poor diet and nutritional deficiencies, and In the case of respiratory problems, having to breath ${ }_{\wedge}^{e}$ the smog that now engulfs Portland and other major cities.

Providing housing for Burnside residents calls for keeping in mind that many of them are disabled. Their disabilities may require them to have walkers, wheel chairs, artificial limbs, crutches, etc, all of which means that the buildings must be free of architectural barriers. They must also be close to stores and other services that they need or be able to get transportation to those services. For the resident who is no longer able to take care of himself, total care facilities providing nursing home services will need to be developed. Other considerations for housing the disabled resident will be discussed further in the conclusion of this paper. It is important to note here that a large number of area residents have disabling diseases that must be taken into consideration when planning for housing.

Any look at characteristics of skid row neighborhoods would not be complete without dealing with the assertion that the area houses transients who have not contributed to the larger community and will be moving out. This may have been true during the depression when men living on skid row often maintained a high degree of mobility so they could move on to any job openings that arose regardless of location. Today, however, skid row residents are not nearly as mobile. 
In his study of Chicago's skid row areas, Donald Bogue's findings support the contention that the majority of present day skid row residents are stable, permanent residents with only $10-15 \%$ being wanderers. This stable population come from largely urban backgrounds and have strong ties to the local community. (Bogue, 1963: 244). In Portland there is a seasonal fluctuation that brings migrant farm workers into Burnside during the summer months. Beyond this however there seems to exist a large core of older, disabled residents who do not migrate and have chosen to retire in Portland. In relating this to housing then, it is important to be aware that very little housing is used by the transient. The majority of the people on Burnside are permanent residents who have established roots in the area and consider this community their home. By providing housing on skid row, Portland will be housing people who have contributed to the community.

The final aspect of skid row living that will be reviewed here concerns a problem in living that older people in every neighborhood in our large cities are encountering - crime. Because they are obviously physically weaker and cannot defend themselves, older people are increasingly being chosen as victims for crime by the stronger and more violent people in our society. Skid row neighborhoods with their high concentration of older people have become increasingly more violent for the older resident. Historically, Burnside has always been a somewhat rough area. As workingmen came into toun to spend their wages and frequent the area's entertainment spots, violence was not all that uncommon. The violent crime on Burnside today, however, is of a different sort. As older people go about their business in the area they are often 
the prey for a younger more violent group of people known as "jackrollers." Jackrollers have been known to steal overything from large sums of money and jewelry to artificial limbs and crutches. Many older and literally defenseless people live in mortal fear of jackrollers and are very careful when they venture out of their hotel rooms. Because of fear of retaliation from the jackroller and a generally unresponsive criminal justice system, these crimes are often not reported to the police. Consequently, there is no totally reliable data to give an accurate picture of the extent of crime on Burnside. ${ }^{6}$ Personal accounts given to this author while working at the Transit Bank, as well as responses from the survey of the Foster hotel (Chapter V), suggest the extent of the problem. Talking with residents, nurses, police, and social service people who all work or live in the area, one becomes increasingly aware of the seriousness of the situation.

With crime taking on such devastating proportions in Burnside, it is important for housing policy for the area to recognize its existence and plan for it accordingly. The resident of any housing in this area must feel safe in his home and be able to acquire services he needs without fearing brutal assaults. Cansequently, the physical structure of the dwelling (is it easy to break into?) and its location (does the attainment of services necessitate walking great distances through dangerous areas?) all become important factors in planning for the structure. Since the general incidence of crime has been increasing and there is little reason to think that it will decrease, planning of safe and secure housing for the older and handicapped resident becomes increasingly important if we are to

Gor a more detailed description of jackrolling and crime in the Burnside area see Transit Bank, by Mike Jones. It contains several interviews with area residents that gives a more detailed description of the situation than is presented here. 
adequately meet the needs of these people.

Burnside residents have clearly served an important function for Portland. They have given Portland a cheap source of manual labor which its industrialists and developers have been able to exploit in order to further their enterprises. In the process the men have been poorly paid, ill housed, ill nourished, employed under conditions which have been injurious to their health. This has insured their aging faster, being disabled longer and dying sooner than the average person in this country. As the Burnside resident has become older and disabled, he also has become less mobile and less able to defend himself against assault. Fear of crime has thus taken on added significance in his life as he decides whether he will venture out of his hotel.

Burnside residents have made major contributions to tinis community. Not only have they contributed their strength to the building of this community, they have contributed something more essential - their health and well being. As they become older and lose their strength and, consequently, their exploitative potential, they become more dependent on society to have their needs met. The remainder of this study will deal with how our society has responded to their need for low cost housing. 


\section{CHAPTER III}

\section{HOUSING TRENDS FOR SKID ROW COMMUNITIES IN OTHER CITIES}

While few were watching, a number of our large and smaller skid rows have disappeared, often leaving only small remnants. A decade ago, Detroit's Michigan Avenue was razed and for the most part, remains unoccupied today. Minneapolis! Gateway Project, whose greater part is parking space, replaced skid row. In St. Louis, the Great Arch project displaced some of skid row. In Chicago in 1970, a multi-million dollar business syndicate bought three core blocks of demolished West Madison skid row . . (Vander Kooi, 1973: 68)

And on and on it goes. To this list of cities who have demolished their skid row areas many more cities could be added. Houstan, Dallas, Cincinnati, Austin, Denver and San Francisco have all undergone "urban renewal" programs designed to eliminate skid row communities. The overall attitude city officials have toward this neighborhood is one of disgust. Most want to demolish these areas as soon as they can get the support to do so.

A good example of this demolition mentality surfaces in the planning report for downtown Denver. In discussing urban renewal for Larimer street, Denver's skid row area, the following account is given.

The area is situated on the lower periphery of the high-use retail and commercial section of downtown. Until recent efforts sparked by downtown interests, the blight of the lower downtown area was gradually intruding upon the higher use area. A great number of substantial uses and activities still exist either within or on the immediate periphery of the area . . .

The Project has plenty of good strong neighbors which certainly is one of the prime requisites for success. But it alsa has some poor neighbors. Larimer Street, once Denver's finest, is a skid-row [sic] jungle which can be defoliated only by a bulldozer. (Moore, 1965: 43) 
In the first paragraph presented here the city officials call attention to the "intrusion" of "blight" of the skid row area on downtown. By its mere existence, skid row is being cast as the farce that will "ruin" downtown. The next paragraph goes on to say that the skid row area should be bulldozed. Denver's city offioials appear one sided in their assessment of who is intruding. The skid row resident who has been in the area for years is called the intruder where the forces wishing to bulldoze his neighborhood are not. The article goes on to state,

Even in the so-called skid-row [sid] area, however, there are some solid businesses which need expansion. These businesses should remain in or near their present locations. Perhaps urban renewal can provide them with a new and better environment. (Moore, 1965: 43)

It is doubtful that these "solid businesses" are the ones that cater to the low income resident. The whole project demonstrates an obvious lack of concern for the skid row resident - a lack of concern shared by many public officials who plan for these areas.

Part of this lack of concern is due to general ignorance about the type of person who lives on skid row. But even when surveys are done to obtain denographic information, it seems to make no difference to developers. Consider the experience in Minneapolis' redevelopment program.

The general view of the inhabitants of the lower loop was that they were drunks and deadbeats. When redevelopment of the area reached an advanced stage, however, a survey was made to guide those responsible for relocation services. The survey showed that the lower loop was not primarily a skid row for transients after all. It was rather a neighborhood of retired, single, old men, most of them very poor but quite sober. (Altshuler, 1967: 201)

The same information gathering process happened in San Francisco just prior to the destruction of its skid row area. Their conclusions about who lived there are similar to those reached by the Minneapolis survey and those presented in chapter one of this paper. In each instance 
the community is a neighborhood for older, disabled, lou income adults who happen to be living on land that developers wish to exploit. Consequently, the residents are falsely derided as being transients and drunks and are forced to move.

In the process of writing his book, Transit Bank, Mike Jones sent letters to city planning departments in 51 U.S. cities with a population of over 100,000 seeking information on their skid row areas. Dut of the 28 cities that responded several stated that they did not have a skid fow in their area. A sampling of those responses are offer below. "This is to advise that the City of Houstan does not contain any specific or singular area which could be identified as 'skid row' . . ."

"Actually, the situation in Dallas is that we have no real skid row area." "Sorry, we do not have a skid row in Austin."

"Cincinnati has no skid row identifiable as such."

"Minneapolis abolished its Skid Row during the 1950's via a downtown urban renewal project." (Jones, 1972: 145)

Each of these letters, prepared by the local city planning departments, denied the existance of a skid row in their city. Their letters state that any skid row type neighborhood that they did have, has now been abolished via urban renewal. What they do not address is where the people noved to after thair neighborhood was destroyed. They indicated that by tearing out physically deteriorating buildings, this form of poverty no longer exists in their cities. Obviously the former residents have to move somewhere. The displacement and relocation never really gets rid of the "blighted" area, but just moves it to another part of toun. Consider the following assessment of urban renewal by Chester Hartman as he discusses this phenomena in relation to San Francisco's skid row. 
"Slum Clearance" is virtually a synonym for urban renewal. One of the central canons of the program is that it will remove slums and thereby eliminate their costs to society . . But the social problems that produce and are produced by "slum environments" - apart from the issue of how that term may be legitimately Jefined - do not disapperr with the physical destruction of the site labeled "slum" or "blighted." Urban renewal may merely be moving the bump along the carpet, by shifting the population and problems to another area of the city. (Hartman, 1974: 181)

A consideration to be made here that is more important than the physical effect on the buildings concerns the effect on the residents. As their neighborhood is destroyed they must find new housing. Federal urban renewal guidelines say that they must get relocation assistance and be assured of a dwelling that is of similar quality and cost as the one they have moved out of. Relocation programs, however, are often cumbersome and most residents have to find their oun housing. That housing is often more expensive than the housing on skid row and does not have the services he became used to on skid row (i.e. hotels, taverns, grocery stores, missions, etc.). He has thus been robbed of his neighborhood culture and those things he has grown accustomed to. With the majority of skid row displaceses being older, this new environment becomes all the nore difficult for them to adjust to. Consider this appraisal by Vander Kooi,

When skid rowers are dislocated a few may improve their life style but at least as many decline to a lower standard of life and die sooner. Uhile some find better housing, more regular jobs and, perhaps, more satisfactory companionship, most do not. At their advanced age they are sent into urban sections where thay are strangers. Even when they get better housing and, with the help of government or skid row workers, improved old age or other assistance, their initial enthusiasm is often replaced by an uneasy, vague lonliness. They miss skid row, their old companions and even some of the things about which they always complained. And often they try to return. (Vander Kooi, 1973: 70)

Since the men being relocated are living on poverty incomes, they 
must look for low rent housing. This often puts them into competition with other low income people for scarce low cost housing and encourages competition among poor people for scarce resources. (Hartman, 1974: 101, 116). This competition is exacerbated by the lifestyle differences among the older skid row person who moves into a neighborhood inhabited by younger people. Thus, the poor are not only deprived of their old hame, but often must fight other poor people for their new one:

This reprehensible way that our society provides for the older warkingclass citizen is standard procedure for most large U.S. cities. The older person is seen as a burden and a blight whose existence constitutes an "intrusion" on non warking class institutions. In the course of researching the material for this chapter, two major findings emerge. First, the response of all cities surveyed to their skid row communities has been to destroy those communities. Second, the relocation experiences of skid row residents has shown this process to be detrimental to their health and safety. In all of the literature reviewed, no indication was found that any city in the United States has sought to improve housing and other conditions in skid row neighborhoods. Portland is going through its own process of determining how it should respond to the Burnside community - the subject of the next chapter. 
CHAPTER IV

HOUSING TRENDS FOR BURNSIDE

Today we look around to see the rubble of the Friendly Home [hotel], the empty rooms of the Phillips, the Camp, the Glade hotel [and] I ask myself why. And if I look around more I see the remnants of the old Burnside hotel, which is now Couch Street Galleries. I look to the old Globe hotel and it is now Import Plaza. The Merchant hotel is now offices and boutiques. The Alco is now going to be the Fish House. The Paul hotel is a parking lot, and the Pamona is now a haunted flop house not because of the arsonists who murdered twelve people, but because of the insensitive owners who turned it into a gallery. I ask you why this $\eta^{\text {is }}$ to happen to us old people? Our housing was our homes.

And so as in other cities, Portland is losing its skid row area not so much by a deliberate policy of destruction, but by the attrition of its housing stock through the gradual land use change of the area. In recent years, Burnside hotels have been closing, farcing the low income, elderly person out of his horne and community. This chapter will (1) focus on the attrition of housing and cite some of its causes, (2) examine the sacial policy for this developed by the Portland Human Resource Bureau, and (3) assess the present state of affairs for low income housing for Portland's skid row resident. The Decline of Low Income Housing

Burnside hatels have been closing down in recent years at a rapid rate. Between 1972 and 1974, 14 hotels in the Burnside and Lowngdale areas

${ }^{1}$ Excerpt from a speech by Everett Lyons, president of the Burnside Area Residents, delivered to the Burnside Voter's Forum on May 10, 1976, at the Downtown Chapel, Portland, Dregon. 
forced to leave his neighborhood? The answer quite clearly is no. First, according to the 1970 census figures, the majority of Burnside residents are paying in excess of $25 \%$ of their income for rent with $32 \%$ of the residents paying in excess of $35 \%$ of their income for rent. With this percentage of their income already going for shelter costs, they cannot afford to pay more. Second, the areas that Burnside residents are most likely to relocate in are the southwest and southeast areas of Portland. According to the Social Policy Report, neither of these areas have sufficient vacancies in their low-income dwellings to house an influx of people from Burnside. Even if the vacancies did exist, the rents are sufficiently higher and would cause much hardship to people whose incomes are as low as those now living on Burnside. Consider the conclusions made by the Social Policy Report,

In the southwest and southeast areas included in the survey, there are few vacant units actually available to absorb any migration from the Burnside-Lounsdale areas. The vacancy rates for the hotels in the areas are fairly consistent, between $10 \%-15 \%$, possibly that percentage of the total reserved for transient lodging. The apartments in both areas are more fully occupied in the lowest rent levels, making it especially difficult to relocate more than a few low income persons.

The rent levels in the area are not comparable to those found in the Burnside-Lownsdale areas. As previously stated, the average rent in the Burnside-Lownsdale areas is now $\$ 38$. In the areas surveyed, less than one-quarter of the total inventory rents for less than $\$ 50$. It is also significant that approximately $89 \%$ of the Burnside-Lownsdale residents pay less than $\$ 50$ per month for rent. Along with the fact that over one-half the residents of Burnside-Lownsdale presently pay over $25 \%$ of their income for rent, it is probable that most of the persons involved would have difficulty relocating in the areas surveyed. (Social Policy Report, 1974: 65-66)

The report goes on to state that in the process of conducting the survey, the researchers encountered negative attitudes about Burnside residents on the part of managers operating the housing in the survey areas. They stated an unwillingness to house people from Burnside. 
The other more subtle pressure of relocation concerns the uprooting of alder people who have lived in a unique neighborhood much of their lives. Their friends, culture and identity lies in the buildings they have lived in, the character of which has not been duplicated in any other part of the city. In discussing this phenamena, sociologist Ronald Vander Kooi states,

The social character of skid row, with its easy acceptance, friendship, and money for lodging, makes it a desirable place for those who have no home affiliations . . Since skid row is so very social, with only the most pathological of man drinking alone in their rooms or seeking isolation, demolition of skid row means that gathering places are razed and cronies separated. (Vander Kooi, 1973: 67)

As Burnside residents are forced to move to other parts of the city they are subjected to both the financial costs as well as the social costs of such a move. The burden of urban renewal and relocation is truly placed on the people with the fewest resources for dealing with it.

\section{Social Policy: Implications for Housing}

On Dctober 8, 1974, the Portland Human Resource Bureau issued a Social Policy Report for the downtown urban renewal area. The authors of the policy report lauded the City Council for requesting social policy recommendations. They saw the City Council as being sensitive to the needs of the residents because city officials wanted to know what kind of disruption the physical renewal of the Burnside and Lownsdale communities would create for the residents.

In completing the report, they purchased consultation services from Irving Shandler, the Executive Director of the Diagnostic and Rehabilitation Center in Philadelphia. Shandler's program in Philadelphia is responsible for systematically removing skid row residents there by putting them in 
"half-way" houses, alcohol recovery programs and other housing outside the skid row area. (Blumberg, 1971: 242-258). His recommendations for social policy for Partlend reflect that attitude.

Because his philosophy for dealing with skid row has a profound influence on the firal recommendations made by the Human Resource Bureau, a discussion of Shandler's report will be presented here. Shandler begins with the assertion that "skid road" is a demoralizing and dehumanizing place for the "marginal" men who live there. The institutions of "skit road" attract these men and eliminating these institutions (flophouses, second hand stores, taverns, etc.) will eliminate "skid road." Shandler therefore recommends that a systematic effort be made to relocate/rehabilitate as many of the residents as possible while their neighborhood is being transformed into an area that serves the city's more affluent. He feels the city should use its regulatory power to close down "skid road" institutions so that the men can "have the opportunity for some alternative lifestyle." (Social Policy Report, 1974: 85)

The report calls for the destruction of the Burnside community as an act of humanity. ${ }^{2}$ He is calling for skid row institutions to be destroyed and residential care facilities and other housing to be established elsewhere. Nowhere in his plans was input from Burnside residents sought out. This has led to the charge that "his recommendations were unrealistic in terms of available resources" and many reviewers questioned whether the residents were being treated as "victims of social planning." (Shadbolt, 1975: 3). Shandler's underlying assertion is that skid row is dehumanthis country's involvement in Viet Nam, i.e. "we're fighting for peace." 
izing and must be destroyed and the city should take an active role in doing that.

The Social Policy Report agrees with the elimination of skid row but calls for the city to take a more gradual "soft cop" approach to the neighborhood destruction. In replying to Shandler's consultation report the Human Resource Bureau makes the following statement,

The Human Resource Bureau and Mr. Shandler agree that skid row life is demeaning and dehumanizing to those that are caught up in its insidious web. There is also agreement that the City should strive to eliminate the current skid road and prevent the formation of new skid roads . . . In general, Mr. Shandler's recommendations rely more heavily on the city's regulatory power to bring about closure of skid road institutions whereas the Human Resource Bureau's approach is to provide alternative living situations outside the core area as a means of making the cluster of skid road services unnecessary...(Social. Policy Report, 1974: 3)

Both start with the underlying assumption that skid row communities are bad and must be destroyed. The only difference between Shandler and the Social Policy Repart is the means of destruction.

The Social Policy Report calls for the gradual "voluntary" dispersal of skid row residents with a small portion of low income housing to be retained in the downtown area. It calls for the various area governments to put their efforts behind renovating some of the existing structures. It cites the census figures which show the Burnside population to be declining in numbers. It then assumes that the papulation will keep on declining through gradual attrition, therefore, making its dispersal voluntary. This voluntary dispersal, however, relies on (1) code enforcement to close the hotels, (2) development pressures to change the buildings to a wsage more consistent with middle-class consumer patterns, and (3) the Public Inebriate Project to move people out of the area into "rehabilitation" programs. 
Though the Social Policy Report tends to put the needs of the Portland business community ahead of the needs of the neighborhoods, it does call for the renovation of some of the existing housing. Part of the overall problem with the Social Palicy Report has not been its conterit, but an absense of observable support from the city. This lack of support has tended to make the report an acedemic exercise. In his critique of the Social Policy Report, Larry Shadbolt claims that the report is full of ambiguities which makes implementation difficult. He states,

It would appear that these problems of implementing the plan can only be resolved by clarifying the basic intent of social policy and then by devising program elements that are consistent with policy. The problem with the social policy to date has been a lack of clear intent backed up by a set of actions to achieve those purposes. One thing has been clear throughout the development of social policy. Even though social problems have been discussed a good deal, very little systematic analysis of the housing problern or research into resident's needs has teen a part of the consultants' or downtown planner's program. (Shadbolt, 1975: 10)

Others would argue that the city is not committed to housing the low income person downtown - especially the Burnside resident. The existence of low income, older people in the downtown area takes away from the "clean" image that some feel downtown businesses need to project if they are going to compete with the suburban shopping centers for customers. Therefore, the city, in alliance with business, is not going to advocate for a social policy that they believe has the potential for reducing or eliminating the commercial development that caters to the middle class consumer. On the other hand, the city does not want to be in the position of forcing older people out of their homes. Consequently, city officials are forced into a position where they cannot act. But by not acting, the city is giving tacit approval to let conditions exist as they do now and 
the only low-income housing unit in the Burnside area. Its version does not talk abaut the high-minded civic leaders who gave of their time and resources because they felt poor people needed housing. Rather, it talks about a system of trade-offs among both public and private interests that produced a low-income housing project at the expense of other housing in the Burnside community. This other story, as well as the research it invited, is the subject of the next chapter. 
THE STUDY

\section{Purpose}

Because of these seeming irregularities, the Transit Bank in conjunction with the Burnside Area Residents and this author decided to conduct a survey of the residents of the foster hotel low income housing project. We wanted to try to examine the following questions:

1). To what extent is the foster hotel providing housing for people who used to live in the old Foster hotel and/ar the Friendly Home hotel?

2). Is the Foster providing housing for people who have made the Burnside community their hame or for people who have come from outside the Burnside community?

3). Who do the current Foster hotel residents want to have live in the Foster and who do they want to keep out?

4). Are the current Foster hotel residents satisfied with their dwelling?

5). What are the attitudes that the current foster hotel residents have concerning the desirability of both public and private housing in the Burnside community?

Study Design and Methodology

The questionnaire consisted of 20 open ended questions designed to give the responents maximum flexibility in their answers. Open ended questions are notoriously difficult to categorize, however, it was felt that since much of what was being asked for concerned resident opinion, flexibility in answering for residents was more important than ease of categorizing for the researchers. 
The Foster hotel houses older people, some of whom cannot read or write proficiently and some whose disabilities, i.e. poor eyesight and poor eye-hand coordination would make it difficult for them to respond in writing to a questionnaire. Therefore, all questions were given orally to the residents and the answers were recorded by the interviewers. The interviewers consisted of two undergraduate social work students from the Portland State University School of Social Work with some assistance being given to them by this author. The interviews took approximately 20 minutes to complete and all the residents in the hotel were contacted. The interviews were conducted two half days per week until all of the residents had been given a chance to respond. The answers were then drawn together and categorized.

The interviewing began in mid-February of 1976 and lasted through most of March. 86 people were living in the Foster at that time and numerous attempts were made to contact all of them. Out of the 86 people, 52 consented to participate in the study. The interviewers felt that the residents who decided not to participate did so for either reasons of privacy or fear of harassment on the part of the housing authority or the screening committee. These were the reasons most often given by those who chose not to participate though many who chose not to do so gave no reason. of those who responded, most answered openly to all questions. Others chose not to respond to questions about the quality of the foster hotel out of fears that by saying anything negative they might be thrown out.

Results

The results of the study will be presented here in a topical manner. First, the identifying information explaining some of the demographic char- 
acteristics of the Foster residents will be presented. Second, each of the questions stated under the purpose part of this study will be restated and followed by information gained from the questionnaire that is appropriate to that heading. Third, conclusions will be drawn from the evidence presented and will be stated in a way that directly relates to the questions and their answers.

This format will not follow the order of the questions on the questionnaire though it will approximate it. It is felt that the above format will give the reader a clearer notion of what the study has shown. Some of the questions asked proved not to be useful. Their information, however, will be presented in passing so that all information obtained will be included in this report. Tables will also be included to help illustrate some of the more important findings.

\section{Identifying Information}

Table I shows that 49 out of the 52 respondents were male or $94 \%$. This approximates the percentage of males living on the Burnside and other skid rows in the United States. ${ }^{3}$

TABLE I

GENDER OF FOSTER HOTEL RESIDENTS

$\begin{array}{lcc}\text { Gender } & \text { Number } & \frac{\%}{49} \\ \text { Male } & 3 & 94 \% \\ \text { Female } & 6 \%\end{array}$

37 of the respondents, or $71 \%$, have lived at the Foster for the eight

3 For a further discussion of gender and streetcorner neighborhoods see Tally's Corner, Liebow, pp. 209-213. 
months since it had opened. The rent which is supposed to be tabulated according to the resident's income varied. The lowest reported morithly rent was $\$ 27$ while the highest was $\$ 70$. The mean rent was $\$ 39.71$. The age of the respondents was distributed between 49 and 77 with the average age being about 60 .

Determinations Made

1). TO UHAT EXTENT IS THE CURRENT FOSTER HOTEL PROVIDING HOUSING FDR PEOPLE WHO USED TO LIVE IN THE OLD FOSTER HOTEL AND/OR THE FRIENDLY HDME HOTEL?

When asked if they had ever lived in the Foster hotel before, 19 out of the 52 respondents, or 37\%, said yea with the rest, or 63\%, saying they had not. When asked the same question about the Friendly Home hotel, 19 people responded affirmatively. Some of the respondents had lived in both the old Foster and the Fribndly Hame hotel while others lived in either one or the other. When these two questions were tabulated collectively the results showed that only 25 out of the 52 respondents, or less than half, ever lived in the old Foster or Friendly Home hatel (see TABLE II). Very few of the respondents were living in either hotel just prior to their clasures either. As TABLE III shows, only 11 of 52 , or about $20 \%$, of the respondents had ever lived in these hotels.

The respondents were also asked how much rent they paid while at the old Foster and Friendly Home hotels and if the security was favorable. This was done to set up a comparison in these areas between the old hotels and the present foster. The rents reported, however, spanned over 30 years of time and were given as daily and weekly, as well as monthly. This made any comparison difficult without working out some sort of complicated ad- 
TABLE II

EVER LIVED IN FOSTER OR

FRIENDLY HOME HOTEL

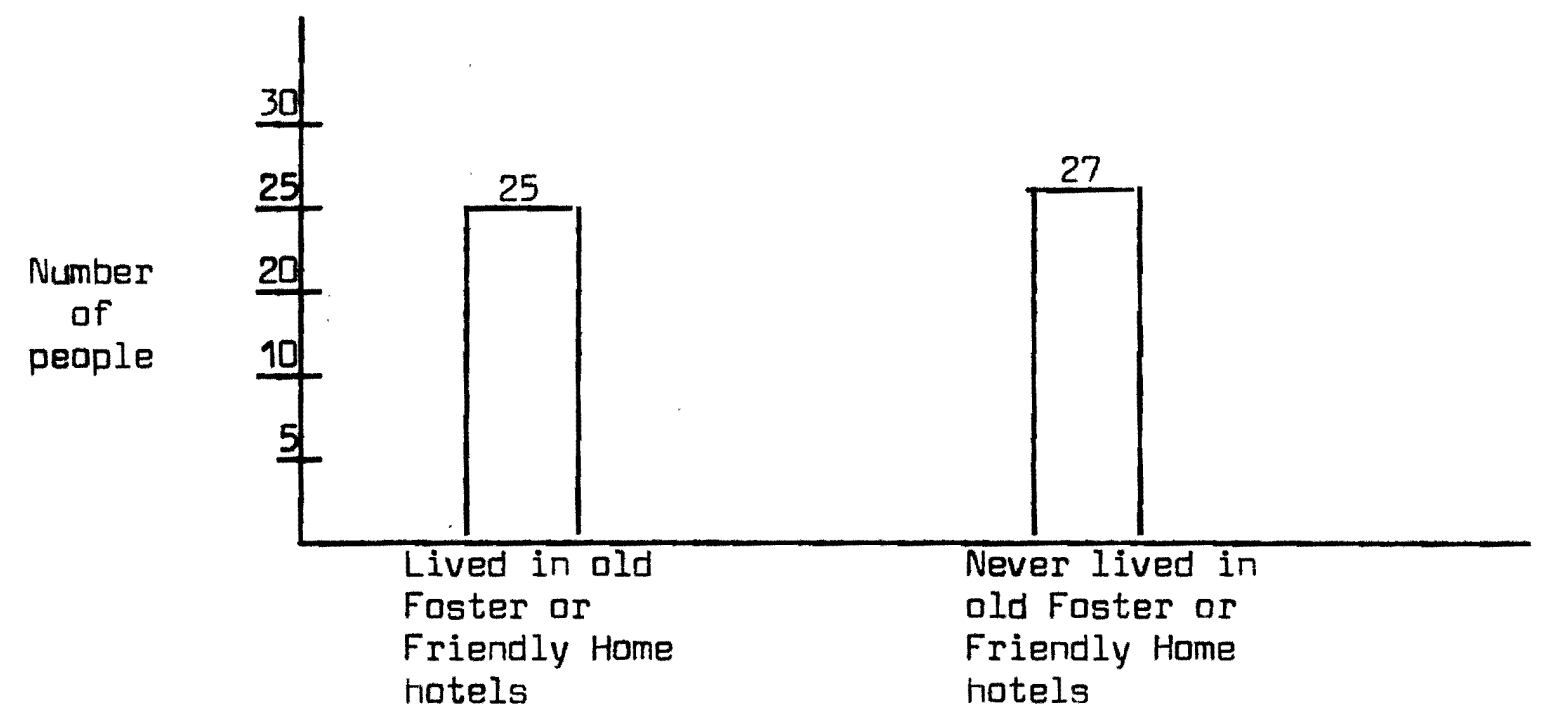

TABLE III

LIVED IN FOSTER OR FRIENDLY HOME HDTEL IMMEDIATELY PRIOR TO CLOSURE

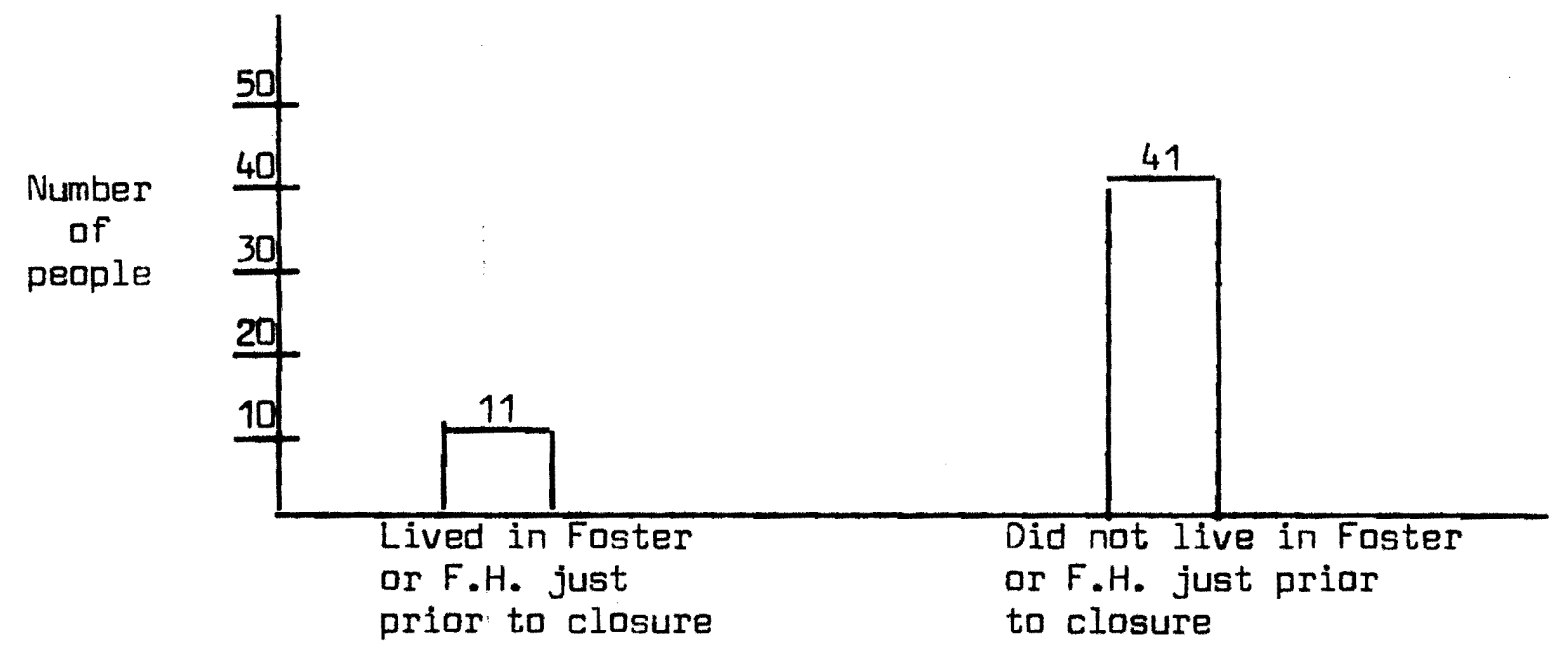


justment formula for inflation. Many of the respondents also had little to say about the security of the old Foster and Friendly Home hotels. The ones who did respond did so subjectively which makes a viable comparison difficult.

Conclusion: Less than one half of the respondents living in the Foster hotel at the time of this study were former residents of the old Foster or Friendly Home hatels.

2). IS THE FOSTER HOTEL PRONIDING HOUSING FOR PEOPLE WHO HAVE MADE THE BURNSIDE COMMUNITY THEIR HOME OR FOR PEOPLE WHO HAVE COME FROM OUTSIDE THE BURNSIDE COMMUNITY?

When asked if they had lived on west Burnside prior to moving into the Foster hotel, 41 respondents, or 79\%, of the population stated they had. However, when they were asked where they lived before moving to the foster, almost one half of the respondents gave addresses outside of the Burnside area (see TABLE IV). Obviously, some of these people have moved around, many spending some of their lives in Burnside housing and some of their lives elsewhere. To get a better idea of how long people have lived in the Burnside community, the total number of years spent there was calculated. The results are shown in TABLE $V$. As indicated by the table one out of two Foster hotel residents have lived less than 10 years on West Burnside and one out of five have never lived on Burnside at all.

Conclusion: One half of the current Foster hotel residents have lived on Burnside less than 10 years and one fifth have never lived on Burnside at all.

3). WHO DO THE CURRENT FOSTER HOTEL RESIDENTS WANT TO HAVE LIVE IN THE FOSTER AND WHOM DO THEY WANT TO KEEP DUT? 
TABLE IV

AREA LIVED IN PRIOR TO THE FOSTER

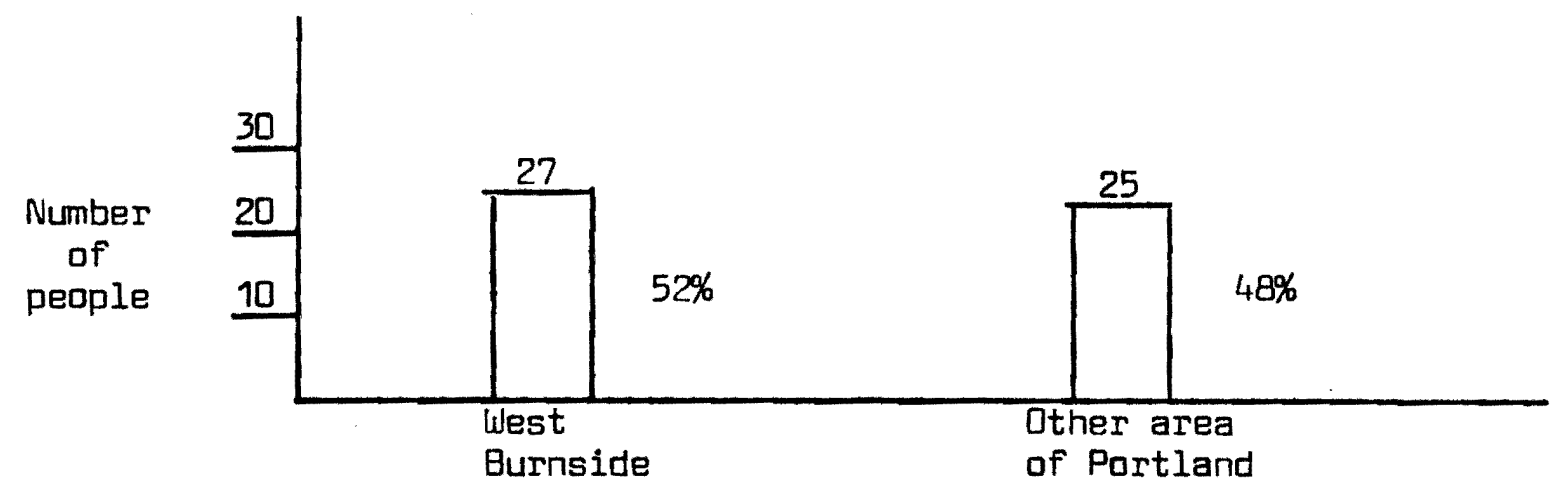

TABLE V

NUMBER DF YEARS LIVED ON BURNSIDE

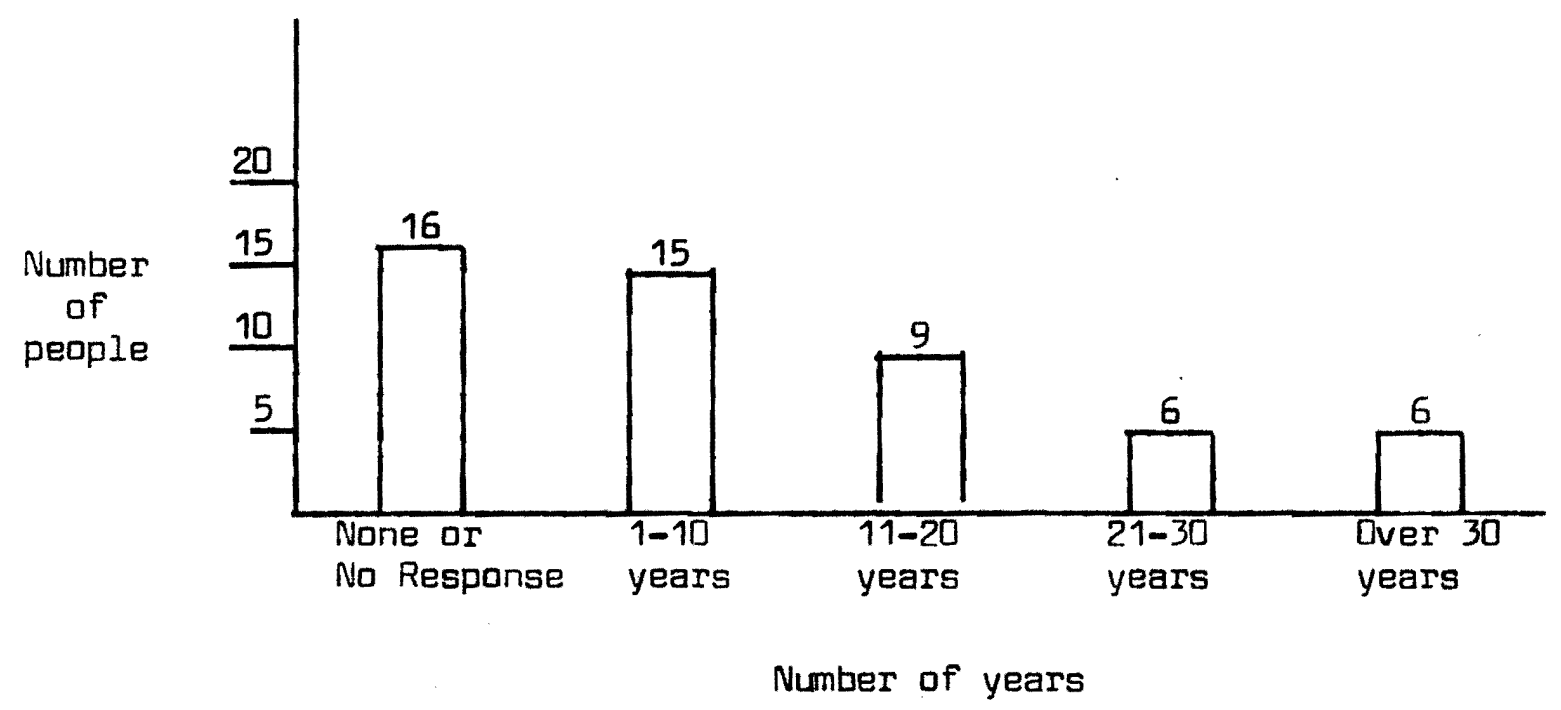


TABLE VI shows the types of people the current foster hotel residents want to have live there.

TABLE VI

TYPES WHO SHOULD BE AT FOSTER

Types want in

Dider

Good, clean, quiet

Mildly disabled

Nontroublesome drinkers

Dther

Low income

All types

Nonalcoholic
Number of responses

$2 \square$

18

17

10

7

5

5

2

In general, the people listed geem to be people much like the respondents or at least how they perceive themselves, i.e. older, clean, etc. The theme of the responses seemed to call for quiet people and people that would be easy to get along with. They also include the category "nontroublesome drinkers" and use this to differentiate this person from the person who becomes unruly when he drinks.

In contrast, TABLE VII shows the types of people the current residents would like to keep out of the Foster. They are all people who in one way or another would disturb other people. They can also be seen as characteristics of people who have always lived in Burnside area and therefore the type of person the Foster initially was supposed to serve. 
TABLE VII

TYPES WHO SHDULD BE KEPT OUT DF FOSTER

Types kept out

Troublemakers

Alcoholics

Dther

Old Jackrollers

Dirty people

Nobody

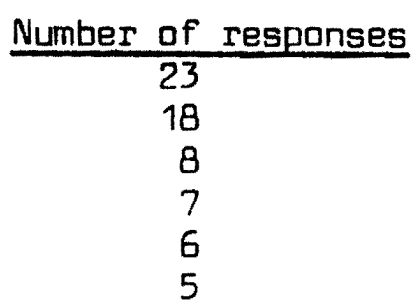

The types of people who should lived at the foster was cross tabulated with the area the people came from to see if there was a relationship here. No significant relationship was found. Likewise the area the respondents came from was cross tabulated with the resident attitudes on the types of people who should by kept out of the foster and no relationship was found.

Residents were specifically asked if the foster hotel should house everyone, including the chronic alcoholic and the severely disabled. Twenty-four residents, or 46\%, stated that chronic alcoholics should be allowed to live in the Foster hotel while 23 respondents, or $44 \%$, stated they should not. The residents tended to be more tolerant of people with severe disabilities although $31 \%$ of the respondents still did not want the foster to house the severely disabled person.

TABLE VIII

ATTITUDES ABOUT CHRONIC ALCOHOLIC

\begin{tabular}{|c|c|}
\hline $\begin{array}{l}\text { Chronic Alcoholic } \\
\text { Should be housed } \\
\text { at Foster }\end{array}$ & $\begin{array}{c}\text { Number } \\
24\end{array}$ \\
\hline $\begin{array}{l}\text { Should not be housed } \\
\text { at Foster }\end{array}$ & 23 \\
\hline No response & 5 \\
\hline
\end{tabular}


TABLE IX

\section{ATTITUDES ABOUT SEUERELY DISABLED}

\begin{tabular}{|c|c|}
\hline $\begin{array}{l}\text { Severely Disabled } \\
\text { Should be housed } \\
\text { at Foster }\end{array}$ & $\frac{\text { Number }}{28}$ \\
\hline Should not be housed & 16 \\
\hline No response & 8 \\
\hline
\end{tabular}

The residents attitudes on whether the chronic alcoholic or severely disabled person should be housed at the Foster were cross tabulated with the number of years the people lived on Burnside, the area the respondents came from, and. whether or not the people were former residents of the foster hotel to see if there was any correlation between them. In all cases there was no significant correlation.

Conclusion: The current Foster hotel residents want to have quiet, nontroublesame, mildly disabled, clean people live in the Foster. They want to keep out the annoying, troublesome alcoholic and the severely disabled person.

4). ARE THE CURRENT FOSTER HOTEL RESIDENTS SATISFIED WITH THEIR DWELLING?

To get an understanding of how the residents felt about the Foster they were asked, (1) to list the things they liked and the things they disliked about the Foster, (2) to comment on the security and crime issues they faced as residents of the Foster, and (3)their general level of satisfaction with their experiences of living at the Foster hotel. When asked what things they liked about the Foster, the respondents listed primarily structural advantages such as the building's safety and cleanliness. (see TABLE $X)$. 
TABLE $X$

ADVANTAGES OF FOSTER

$\begin{array}{lc}\frac{\text { Advantage }}{\text { Structural }} & \frac{\text { Number }}{35} \\ \text { Non-structural } & 20 * \\ \text { *Total will add to more than } 52 \text { as } \\ \text { respondents could list more than } \\ \text { one advantage. }\end{array}$

TABLE XI

DISAOUANTAGES OF FOSTER

Disadvantage

Structural

Non-structural $\frac{\text { Number }}{7}$

17

When asked what they disliked about the foster the residents listed non-structural disadvantages such as getting along with the management or disliking the neighborhood. (see TABLE XI).

The majority of the residents $(71 \%)$ felt the security at the Foster was adequate. Of those who felt the security was inadequate or could use. improvement (25\%), four specific security issues were listed - (1) no night coverage at the desk, (2) room doors that do not lock, (3) no hall patrols to keep the halls safe and (4) too easy entry through the frorit door. All of these issues seem fairly easy to remedy. But even with these drawbacks, the Foster residents in general felt safe. TABLE XII shows one half of the residents having heard of or having had an experience with a crime within the foster. TABLE XIII states that the vast majority of residents feel that security has stayed the same or impraved since the opening of the Foster. 
TABLE XII

CRIMES OCCURRING IN FOSTER

\begin{tabular}{lcc} 
Crime experiences & Number & $\underline{\%}$ \\
\cline { 2 - 3 } Had experienced crime & 5 & $10 \%$ \\
in Foster & & \\
Had heard of crime & 21 & $40 \%$ \\
Neither & 26 & $50 \%$
\end{tabular}

TABLE XIII

STATUS OF SECURITY AT FOSTER

\begin{tabular}{lcc} 
Security & Number & $\underline{\%}$ \\
\cline { 2 - 3 } $\begin{array}{l}\text { Gatten more secure } \\
\text { since opening Foster }\end{array}$ & 24 & $46 \%$ \\
Stayed the same & 21 & $40 \%$ \\
$\begin{array}{l}\text { Gotten less secure } \\
\text { since opening Foster }\end{array}$ & 2 & $4 \%$ \\
No response & 5 & $10 \%$
\end{tabular}

When asked about the architecture, $85 \%$ of the respondents stated they liked the architectural layout of the Foster and only 10\% stated they did not with 6\% giving no response. When asked if they felt their living quarters were adequate, 47 of the respondents, or 90\%, stated they were. 96\% of the respondents indicated they were happy living at the Foster. Conclusion: In general, the people living at the Foster like the facility and are satisfied with their home. They also liked some of the structural advantages of the Foster over other places they had lived. For the most part they felt the security was good, however, they did offer some concrete suggestions for improvement, i.e. locks on doors, night desk coverage, hall partrols and more limited access to the front door. 
5). WHAT ARE THE ATTITUDES THAT THE CURRENT FOSTER HOTEL RESIDENTS HAVE CONCERNING THE DESIRABILITY OF BDTH PUBLIC AND PRIVATE HOUSING IN THE BURNSIDE COMMUNITY?

Though they like the Foster hotel, most respondents do nat feel that public housing should house everyone. They feel that private housing does have a place in the Burnside comminity (see TABLES XIV AND XV). Many people commented that they felt a mix of the public and private housing was preferable to all of one or the other.

TABLE XIV

SHOULD ALL BURNSIDE HOUSING BE PUBLIC?

\begin{tabular}{lcc} 
Public housing & Number & $\frac{\%}{13}$ \\
\hline Should be public housing & $36 \%$ \\
Should not be public & 36 & $69 \%$ \\
housing & 3 & $6 \%$ \\
No response &
\end{tabular}

TABLE XV

DOES PRIVATE hOUSING HAVE PLACE ON BURNSIDE?

$\begin{array}{lcc}\text { Private housing } & \frac{\text { Number }}{34} & \frac{\%}{65 \%} \\ \text { Private housing has place } & 9 & 17 \% \\ \begin{array}{l}\text { Private housing does not } \\ \text { have place }\end{array} & 9 & 17 \% \\ \text { No response } & 9 & \end{array}$

It was felt that people in the old Foster hotel may have felt that private housing had a place on Burnside to a larger degree than people who had not lived in the old Foster. Consequently, the attitudes on public and private housing were cross tabulated with the people who previously lived in the old Foster hotel. There was no significant difference between 
their attitudes and the other respondents.

Conclusion: The majority of the respondents feel that not all Burnside housing should be public and private housing does have a place in the Burnside community.

\section{Implications}

The current residents of the Foster hotel are satisfied with their living quarters. They like the building, the rent and the management. They have some argument with the security arrangements but are generally satisfied with that, too. They do not want to see public housing take over entirely from private housing. In general, public housing via the Foster hotel has been quite popular with the people who live there and, therefore, has earned a place in the Burnside cormunity.

The problem with the Foster however, has not been the way it has served its residents because it has served them well. The problem has been with the way it has served the community. Consider the following summary of what has been presented in this chapter.

Point - When the Northwest Natural Gas Company wanted to build their "superblock" in the Burnside area, they needed to tear down the Friendly Home hotel. Both the city and private industry committed themselves to house the residents displaced by the destruction of the Friendly Home hotel and the evacuation of the old Foster.

Point - The old Foster hotel and the Friendly Home hotel housed the chronic alcoholic and the severely disabled person that most hotels in the area refused to serve.

Paint - The current Foster hotel has a screening cammittee which determines who is allowed to move into the Foster, thereby leaving the 
decision of who moves into the Foster up to the residents.

Point - The prevailing attitude of the current residents is to keep out the chronic alcoholic and the severely disabled person.

Therefore, a system has been set up by the Housing Authority which

discriminates against the type of resident the foster hotel was initially established to house. This system is causing the Foster to become an exclusive club - those excluded being the residents whose housing was destroyed in the first place.

Many of the residents who frequent the Transit Bank have complained about the operation of the Foster hotel. They are well aware of the discrimination policies and resent them deeply. They also resent city officials who see the existence of the foster hotel as a sign of committment to the neighborhood. Consider this excerpt from a letter from Portland's mayor, Neil Goldschmidt, to the Burnside Voter's Forum,

In the past 3 years I have tried as mayor to work in 2 key areas of concern to the Burnside area residents - housing and direct services. The Foster hotel project is one sign of our committment to retain and upgrade housing in the Burnside neighborhood. The City Planning Bureau, the Housing Authority, the Portland Development Commission, the First National Bank of Dregon, Bill Naito, all took a positive attitude believing that there was a real value both to Burnside and to the larger community in preserving, providing and improving housing in the Burnside area. The Foster hotel project remains a national example of low cost housing rehabilitation in a downtown area...

Burnside has been a changing area over the past 3 years changing as a place to live, a place to work, a place for people. I have worked to keep in touch with these changes and to guide the environment in a direction that respects the humanity and ${ }_{4}$ concerns of the people who live in the Burnside community.

${ }^{4}$ This letter was delivered to the Burnside Area Residents at the Burnside Voter's Forum held on May 10, 1976, at the Downtown Chapel. 
This letter was read to the Burnside area residents who were in attendance at the Voter's Forum. The residents responded to it with the jeers its insensitivity deserved. 
Altshuler, Alan. The City Planning Process; A Political Analysis. Ithaca, New York: Cornell University Press, 1965, 1967.

Anderson, Monty K. et al. "The Lounsdale Community." Portland: Portland State University Urban Studies Center, 1971.

Bahr, Howard M. "The Gradual Disappearance of Skid Row," Social Problems, Vol. 15, Summer, 1967, p. 43.

Bahr, Howard M. and Caplow, Theodore. ld Men Drunk and Sober. New York: New York University Press, 1974.

Bogue, Donald J. Skid Row in American Cities. Chicago: University of Chicago Press, 1963.

Blumberg, Leonard et al. "The Development, Major Goals, and Strategies of a Skid Row Program: Philadelphia," Quarterly Journal of Studies on Alcohol, Vol. 27, 1966, pp. 242-258.

Blumberg, Leonard et al. Relocation Services to 5kid Row Men. Philadelphia: Diagnostic and Rehabilitation Center, 1968.

Blumberg, Leonard et al. Skid Row and Its Alternatives; Research and Recommendations From Philadelphia. Philadelphia: Temple University Press, 1973.

Blumberg, Leonard et al. "The Skid Row Man and the Skid Row Status Community," Quarterly Journal of Studies on Alcohol, Vol 32, 1971, pp. 909941.

Brush, Thomas. "Believing In Dreams," Poetry Northwest, Winter 1975-76, pp. 3-4.

Center for Population Research and Census and Center for Urban Studies. "A Survey of Demand for Housing in Downtown Portland." Portland: CPRC Survey Series No. 40, 1975.

Citizens Advisory Committe to the Dountoun Plan. "Minority Report: Citizens!' Advisory Committee To The Downtown Plan." Portland: City of Portland, May, 1973.

Ennis, T.w. "Bowery Hotel where Derelicts Slept Being Converted to Artists' Studios." New York Times, August 6, 1967, section 8.

Friedman, Ralph. Tales Dut of Oregon. Portland: Pars Co., 1967. 
Hartman, Chester. Yerba Buena: Land Grab and Community Resistance in San Francisco. San Francisco: Blide Publications, 1974.

Holbrook, Stewart. Far Corner; A Personal View of the Pacific Northwest. New York: Macmillan Co., 1952.

Holbrook, Stewart. Holy Old Mackinaw. New York: Macmillan Co., 1956.

Human Resource Bureau. "Social Policy Report for the Downtown Urban Renewal Area." Portland: City of Portland, 1974.

Liebow, Elliott. Tally's Corner. Boston: Little, Brown, 1967.

Jones, Michael P. Transit Bank. Portland: Skid Row Transit Authority, 1972.

Kittrie, N.N. The Right to be Different. Baltimore: Johns Hopkins Press, 1971.

Levy, Herbert. "Needed: A New Kind of Single Room Dccupancy Housing," The Journal of Housing, No. 11, 1968, pp. 572-577, 579-580.

McCusker, Michael. "PGE Invades Waterfront," Metropolis, November, 1973, pp. 3-5.

Moore, Mechlin D., ed. Downtown Denver; A Guide to Central City Development. Washington: Central City Council, Urban Land Institute, 1965.

National Opinion Research Center. The Homeless Man on Skid Row. Chicago: Tenants' Relocation Bureau, 1961.

Pintarich, Paul. "Old Portland Tunnels Explored to Pen History of Shanghaiing," The Dregonian, November 22, 1976, section $D$.

Rooney, J.F. "Group Processes Among Skid Row Winos: A Re-evaluation of the Undersocialization Hypothesis," Quarterly Journal of Studies on Alcohol, Vol. 22, 1961, pp. 444-460.

Rosenbaum, Fred M. "The Downtown Plan and Housing: A Commentary." Portland: Unpublished student paper for Portland State University, 1975.

Rubington, Earl. "The Bottle Gang," Quarterly Journal of Studies on Alcohol, Vol. 29, 1968, pp. 943-955.

Rubington, Earl. "The Changing Skid Row Scene," Quarterly Journal of Studies on Alcohol, Vol. 32, 1971, pp. 123-135.

Shadbolt, Larry M. "Social Policy for Downtown Plan." Portland: Unpublished report to Commissioner Jordan's Office, 1975.

Shapiro, Joan. "Group Work With Urban Rejects In a Slum Hotel," Social Work Practice, 1969. 
Shapiro, Joan. "The Entry Phase In Social work With Slum Hotel Residents." New York: Published by United Neighborhood Houses of New York, Inc., 1968.

Shapiro, Joan. "SRO; Community of the Alone," Social work, Vol. 11, No. 4, 1966, pp. $24-33$.

Skidmore, Owings, and Merrill Environmental Study Group. "Urban Design and Program." Portland: Portland Development Commission, 1971.

Spradley, J.P. You Owe Yourself a Drunk; An Ethnography of Urban Nomads. Boston: Little, Brown and Co., 1970.

Vander Kooi, Ronald. "The Main Stem: Skid Row Revisited," Soceity, September/October, 1973, p. 67.

Wallace, Samuel E. Skid Row As a Way of Life. Totowa, New Jersey: Bedminster Press, 1965.

Wallace, Samuel E. "The Road to Skid Row," Social Problems, Summer, 1968, pp. 92-105. 